\title{
Interactions among insect-resistant soybean genotypes extracts with populations of Anticarsia gemmatalis Hübner (Lepidoptera: Noctuidae) susceptible and resistant to its nucleopolyhedrovirus
}

\author{
GIORLA C. PIUBELLI ${ }^{1,2}$, FLÁVIO MOSCARDI ${ }^{2}$ and CLARA B. HOFFMANN-CAMPO ${ }^{2}$ \\ ${ }^{1}$ Departamento de Zoologia, UFPR, Caixa Postal 19020, 81531-980 Curitiba, PR, Brasil \\ ${ }^{2}$ Embrapa Soja, Caixa Postal 231, 86001-970 Londrina, PR, Brasil \\ Manuscript received on January 15, 2009; accepted for publication on April 30, 2009; \\ presented by ELIBIO L. RECH
}

\begin{abstract}
Anticarsia gemmatalis nucleopolyhedrovirus (AgMNPV) is being used in Brazil as a biological insecticide. Host plant resistance of soybean to insects is been searched for and some authors have mentioned the interference of plant chemistry in virus efficiency. Interactions among soybean extracts of genotypes used as a source of resistance (PI 274454 and PI 227687) with different AgMNPV concentrations in populations of A. gemmatalis susceptible (S) and resistant (R) to the virus were studied at laboratory condition. Higher mortality was observed when larvae fed on diets with extracts of the soybean genotypes compared with those fed on a plain diet (control). The mean lethal concentration $\left(\mathrm{LC}_{50}\right) \mathrm{was}$ reduced about 10 times in the S-population fed on diets containing PI 274454 extracts and different concentrations of AgMNPV, compared to control diet. Additive effect was predominantly observed when larvae fed on diets with extracts of soybean genotypes (PI 274454 and PI 227687) and AgMNPV for both larval populations. The pupal weight was negatively influenced by the extracts incorporated to the diets compared to control, for both larval populations, notably for R-population. The results suggest that, in general, leaf extracts of soybean resistant genotype did not cause any harmful effect on virus efficiency.
\end{abstract}

Key words: velvetbean caterpillar, baculovirus, leaf extracts, resistant genotypes, soybean.

\section{INTRODUCTION}

The multiple nucleopolyhedrovirus of the velvetbean caterpillar, Anticarsia gemmatalis Hübner (Lepidoptera Noctuidae) (AgMNPV) is used regularly in Brazil as a biological insecticide (Moscardi 1999). Peak annual AgMNPV usage occurred in the season 2002/2003, when, about 2.0 million hectares of soybean Glycine $\max$ (L.) Merrill (Fabaceae) were AgMNPV-treated (Hoffmann-Campo et al. 2003, Moscardi and Souza 2002), representing an important alternative to the conventional chemical insecticide sprayings. In parallel, host plant resistance has been studied to control the

Correspondence to: Dr. Flávio Moscardi

E-mail: moscardi@cnpso.embrapa.br major soybean insect pests and two resistant genotypes have been identified, PI 227687 and PI 274454, which contain higher concentrations of rutin (quercitin 3-Orutinoside) compared to other genotypes (HoffmannCampo et al. 2001, Piubelli et al. 2005). Rutin plays an important role in soybean defense against defoliator insects, such as Heliothis virescens (F.) (C.B. HoffmannCampo, unpublished data), Trichoplusia ni (Hübner) (Hoffmann-Campo et al. 2001) and A. gemmatalis (Hoffmann-Campo et al. 2006). In spite of not exerting dramatic effect on the mortality of soybean pests, rutin and chlorogenic acid may act as digestibility reducers (Isman and Duffey 1982) and, consequently, increasing the concentration of this flavonoid and other phenolic compounds would be a good approach to improve soy- 
bean resistance against leaf-feeding insects. Even the less potent digestibility reducers may directly affect herbivores not only by impairing growth and reducing fertility, but also by decreasing disease resistance (Price et al. 1980). One potential negative effect of this control approach is the reduction of natural enemy's efficacy. Felton and Duffey (1990) related that phenolics, including rutin and chlorogenic acid, inhibited infection by the Helicoverpa zea (Bodie) nucleopolyhedrovirus (HZNPV) and extended the survival time of this insect. As a result, a compound that can reduce viral efficacy may compromise baculovirus compatibility with host plant resistance (Hoover et al. 1998).

Due to the extension of the treated area with AgMNPV in soybean in Brazil, baseline studies on the levels of susceptibility of the caterpillar to AgMNPV populations became increasingly important, especially in regions with larger frequency of application of this virus (Moscardi and Sosa-Gomez 1992). In spite of the AgMNPV utilization by soybean growers since 1983, cases of A. gemmatalis resistance to the virus have not been observed in the field (Abot et al. 1995, Sosa-Gomez and Moscardi 2001). However, studies performed simultaneously by Embrapa Soja in Brazil, and University of Louisiana in the USA, showed that under laboratory conditions of high selection pressure (constant exposure to a $\mathrm{LC}_{80}$ ), it is possible to obtain AgMNPV-resistant populations of A. gemmatalis in three to four generations (Abot et al. 1996, Sosa-Gomez and Moscardi 2001). Information on trithrophic interactions is essential for the development of resistant genotypes that are compatible with biological control agents as the efficacy of baculoviruses can be modified by host-plant chemicals (Hoover et al. 1998). In this study, we evaluated the interactions of AgMNPV and extracts of two insect-resistant genotypes (PI 227687 and PI 274454) and tested the hypothesis that the AgMNPV-resistant population of A. gemmatalis would be less afected by such interaction.

\section{MATERIALS AND METHODS}

\section{InSECt POPULATIONS AND VIRUS}

The resistant (R) and susceptible (S) populations of $A$. gemmatalis to AgMNPV were obtained from the insect mass rearing laboratory at Embrapa Soja, Londrina, PR, where these populations have been maintained since 1994. Both original insect colonies ( $\mathrm{S}$ and $\mathrm{R}$ ) were established from larvae collected at the same time from a soybean field, in the region of Sertanópolis, PR, according to the procedures of Abot et al. (1996). The first generation of caterpillars was fed on soybean leaves and since then maintained at the laboratory on artificial diet, according to Hoffmann-Campo et al. (1985). The AgMNPV R-colony was virus-challenged through laboratory selection pressure $(80 \%$ mortality in each generation), according to the methodology described in Abot et al. (1996). The S population was maintained at the same condition but unchallenged. During the present studies, the resistant ratio of the selected (resistant) population in relation to the unselected (susceptible) one was around 100,000 fold. The AgMNPV inoculum's was the isolate LD 79 (obtained from dead larvae in soybean, in the region of Londrina, and housed at the Embrapa Soja virus collection). This AgMNPV isolate was first multiplied on A. gemmatalis larvae, partially purified through standard procedures (Morales et al. 2001), and formulated into a wettable powder formulation to be used in the bioassays.

Preparation of CRUde EXTRACTS FROM PI 227687

AND PI 274454 GENOTYPES

The insect-resistant soybean genotypes (PI 227687 and PI 274454) were grown in greenhouse. Leaves were collected at soybean V6 phenological stage (Fehr and Caviness 1977), oven-dried and ground for extract preparation. From each genotype, $100 \mathrm{~g}$ of dry leaves were soaked in a $1,200 \mathrm{ml}$ of $40 \%$ aqueous ethanol $(\mathrm{EtOH})$ solution in 4,000-ml Becker. This amount was calculated based on the total dry weight of the diet ingredients to make up $500 \mathrm{ml}$ of diet. The genotypes PI 227687 and PI 274454 were selected because they contain the highest amounts of rutin and genistin, i.e., like $3.682 \mathrm{mg} / \mathrm{g}$ and $0.122 \mathrm{mg} / \mathrm{g}$ of dry leaves, on the former, and of $1.472 \mathrm{mg} / \mathrm{g}$ and $0.258 \mathrm{mg} / \mathrm{g}$ of dry leaves on the latter (Piubelli et al. 2005). The recipient with dry leaves and solvent was mixed at 100 r.p.m. for about $18 \mathrm{~h}$, when the extract was filtered through Buckner funnel using Framex ${ }^{\circledR}$ fast filtration paper. The extract was reduced to a final volume of about $20 \mathrm{ml}$ in rotatory evaporator (60 r.p.m) in water bath $\left(40^{\circ} \mathrm{C}\right)$ and eluted in an open 
chromatographic glass column $(3.0 \times 25.0 \mathrm{~cm})$ with the adsorbent Amberlite XAD-4 (Rosler and Goodwin 1983) to remove interfering substances. The column was washed with $259 \mathrm{ml}$ of water $\mathrm{pH} 2.0$ (acidified with $\mathrm{HCl}$ $1.0 \mathrm{~N}$ ) and $500 \mathrm{ml}$ of water $\mathrm{pH} 7.0$, followed by $2,100 \mathrm{ml}$ of $80 \%$ methanol $(\mathrm{MeOH})$. The resulting elutes from the water washes $(\mathrm{pH} 2.0$ and $\mathrm{pH} 7.0)$ were discarded and the eluate from the $\mathrm{MeOH} 80 \%$ wash was concentrated on a rotatory evaporator. The concentrated extract was maintained in freezer $\left(-17^{\circ} \mathrm{C}\right)$ until use.

\section{BioAssay Procedures}

Larvae from A. gemmatalis $\mathrm{S}$ and $\mathrm{R}$ populations were reared from eclosion to late second ínstar (pre-molt to third instar) in disposable 100 ml-cardboard cups, in artificial diet (Greene et al. 1976, modified by HoffmannCampo et al. 1985) containing extracts of the PI 274454 or PI 227687 genotypes. It was used normal plain diet without adding extracts as control. At pre-molt to third instar, caterpillars were transferred to plastic cups with diet containing genotype extracts and different concentrations of the virus, where the insects were kept until pupation.

Samples of the formulated biological insecticide (AgMNPV) and soybean extracts were incorporated into the insect diet at $50^{\circ} \mathrm{C}$. Five concentrations of the virus were added in the diets according to Morales et al. (1997, 2001). Concentrations in the test with S population were $60,180,540,1600$ and 4,860 occlusion bodies (OB)/ml of diet and were 393,600, 1,181,000, $3,543,000,10,600,000$ and $31,900,000 \mathrm{OB} / \mathrm{ml}$ of diet for those from the $\mathrm{R}$ population. A plain diet without the addition of plant extracts and virus was used as control. After diet cooling down and hardening, 30 pre-molt third instar larvae from each treatment were transferred to 50-ml plastic cups (three larva/cup). The experiment was replicated twice for the $\mathrm{R}$, and three times for the $\mathrm{S}$ insects. After treatment, the insects were kept in environmental chambers at $25^{\circ} \pm 2{ }^{\circ} \mathrm{C}, 70 \pm 10 \% \mathrm{RH}$ and, 12L: $12 \mathrm{D}$ photoperiod. Insect mortality was daily evaluated, starting from the $5^{\text {th }}$ day after treatment. Pupae obtained from each treatment were weighed, individualized in plastic vials with vermiculite and returned to the environmental chambers for the observation of adult emergence. Those that failed to emerge as adults were considered in the total amount of insect mortality of the larval phase.

Probit analysis (Finney 1971) was used to estimate mean lethal concentrations $\left(\mathrm{LC}_{50}\right)$, mean lethal times $\left(\mathrm{LT}_{50}\right)$, and associated parameters, such as 95\% fiducial limits of $\mathrm{LC}_{50}$ 's and $\mathrm{LT}_{50}$ 's, slope (b), and chi-square $\left(\chi^{2}\right)$ values. The type of interactions among soybean extracts with the AgMNPV in S and R populations was estimated following the formula $\mathrm{Mm}+q=\mathrm{Mm}+$ $M q(1-M m / 100)$ proposed by Benz (1971), in which: $\mathrm{Mm}$ is the mortality caused by the microorganism (AgMNPV); $M q$ the mortality due to the diet (extracts and/or rutin) and $\mathrm{Mm}+q$ the expected mortality of the mixture (AgMNPV $\times$ extracts and/or rutin). According to this equation, an antagonistic effect occurs when the expected mortality of the mixture $(\mathrm{Mm}+q)$ is significantly lower than the observed mortality. An additive effect occurs when the observed mortality is not significantly different from the expected mortality; and a synergistic effect when the observed mortality is significantly higher than the expected mortality. The significance among the observed and expected mortality was analyzed by the chi-square test $\left(\chi^{2}\right)$, according to Banzatto and Kronka (1992), at 5\% of probability.

For statistical analysis of pupae weight, a completely randomized design was used for the factorial experiments with three diets, five AgMNPV concentrations plus a control, and an unbalanced number of replicates. ANOVA was performed and the treatment means were compared by Tukey test at $5 \%$ of probability. In case of a significant interaction diet $\times$ AgMNPV, a study was performed within each factor in all levels, and the means inside of each factor were analyzed by the Tukey test at $5 \%$ of probability. All data were analyzed by statistical package SAS-Statistical Analysis System for PC (SAS Institute 1996).

\section{RESULTS}

Higher mortalities were observed when caterpillars were fed on diets containing extracts of insect resistant soybean genotypes, in comparison with caterpillars fed on diet without addition of plant extracts (Fig. 1). A positive correlation was observed between larval mortality and different AgMNPV concentrations in all treatments. When the interaction of the PI 227687 and PI 274454 

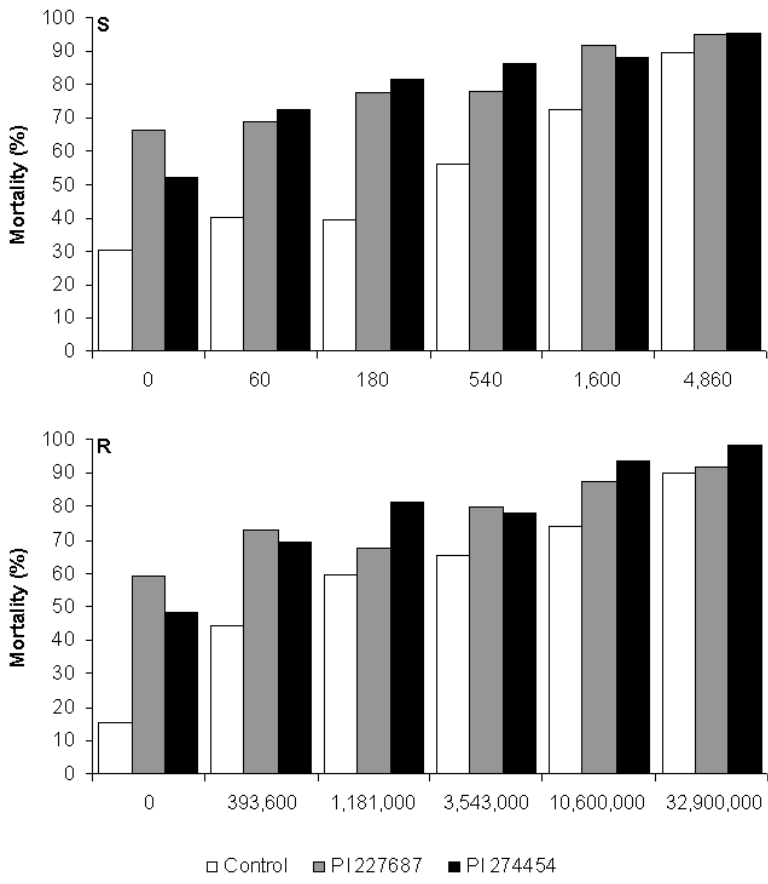

Fig. 1 - Percentage of mortality of $A g M N P V$-susceptible (S) and resistant populations (R) of Anticarsia gemmatalis fed on artificial diet (control) or plus soybean extracts (PI 274454 and PI 227687) and their interactions with six concentrations of the nucleopolyhedrovirus.

extracts with the highest viral concentration was considered, larval mortalities were, respectively, 95.0\% and 95.5\% for the AgMNPV S-population, and 91,9\% and 98,3\% for the AgMNPV R-population. In diets without extracts, when adding the largest concentration of the virus, $89.5 \%(\mathrm{~S})$ and $90.2 \%(\mathrm{R})$ of the caterpillars died.

The presence of the PI 274454 extract in the insect diet containing different concentrations of AgMNPV led to a reduction of about 10-fold in $\mathrm{AgMNPV} \mathrm{LC}_{50}$ values for the A. gemmatalis S-population in comparison with the $\mathrm{LC}_{50}$ of control-diet fed insects (Table I). While the $\mathrm{LC}_{50}$ on $\mathrm{AgMNPV}+\mathrm{PI} 274454$ treatment was of 95.0 $\mathrm{OB} / \mathrm{ml}$ of diet, the $\mathrm{LC}_{50}$ of AgMNPV + plain diet (control) was of $989.3 \mathrm{OB} / \mathrm{ml}$. In spite of observing a reduction trend for the $\mathrm{LC}_{50}$ of PI 227687 extract + AgMNPV, in relation to a plain diet $+\mathrm{AgMNPV}$, the difference between these treatments cannot be considered significant due to the overlapping of the respective $95 \%$ fiducial limits (FL) (Table I).

The $\mathrm{LC}_{50}$ of the AgMNPV + PI 274454 treatment in the resistant population was half of the $\mathrm{LC}_{50}$ of the control and three times lower than the $\mathrm{LC}_{50}$ of the PI 227687 + virus treatment. However, the differences among these treatments were not significant, considering the overlapping of the $95 \%$ FL (Table I). The nonsignificant values of $\chi^{2}$ on the Table I indicate that the Probit model that was used (Finney 1971) was appropriate to the data analysis.

No differences in $\mathrm{LT}_{50}$, for the highest virus concentration, considering the FL, were observed comparing S-insects fed on a plain diet with those that fed on diets containing soybean extracts (Table II). Estimated LT $_{50}$ ranged from 8.66 days (control) to 8.42 days (PI 274454 extract diet). However, $\mathrm{LT}_{50} \mathrm{~s}$ estimated for R-insects were lower in those fed on diet containing both soybean extracts, ranging from 8.91 to 6.72 days in insects fed on control diet and on PI 274454 extract diet, respectively. Following the formula proposed by Benz (1971), the additive effect of soybean extracts and $A g \mathrm{MNPV}$ was, in general, prevailing for larvae of both resistant $(\mathrm{R})$ and susceptible (S) populations of $A$. gemmatalis (Table III), as there was no difference between the observed and expected insect mortality. However, in the R-population, an antagonistic effect was observed when 1,181,000 viral $\mathrm{OB} / \mathrm{ml}$ of diet plus PI 227687 extract was used.

The pupal weight was negatively influenced by the addition of plant extracts and AgMNPV concentrations in the diets (Tables IV and V). There was no significant interaction among diets and $A g M N P V$ concentrations in the S-population and, thus, data were pooled within the type of diet (Table IV). The highest pupal weight means of pooled data were achieved when caterpillars were fed on a plain diet without the addition of extracts followed by those fed on diet amended with PI 274454 and PI 227687 extracts. A negative correlation was observed in pooled means of pupal weight of the S-population; when virus concentration increased in the diet, pupal weight decreased. In the average of the three diets, the largest pupal weights were observed when insects fed on plain diets without virus. In comparison with insects fed on plain diets without virus, the smallest pupal weights were observed when larvae fed on diets containing the highest concentrations of $A g \mathrm{MNPV}$, i.e., 1,600 and 4,860 viral $\mathrm{OB} / \mathrm{ml}$ of diet, respectively (223.1 $\mathrm{mg}$ and $220.3 \mathrm{mg}$ ).

The interaction between plant extracts and different concentrations of AgMNPV in the resistant population 
TABLE I

Median lethal concentrations $\left(\mathrm{LC}_{50} \mathrm{~s}\right)$, fiducial limits $(95 \%)$, slope $( \pm \mathrm{SE})$ and qui-square $\left(\chi^{2}\right)$ of AgMNPV susceptible and resistant populations of Anticarsia gemmatalis ( $A g M N P V)$ fed on soybean extracts (PI 274454 and PI 227687) or on control (plain diet) and different concentrations of $A g M N P V$.

\begin{tabular}{|c|c|c|c|c|}
\hline Treatments & $\mathrm{LC}_{50}^{1}$ & Fiducial limits $(95 \%)$ & Slope \pm SE & $\chi^{2 *}$ \\
\hline \multicolumn{5}{|c|}{ AgMNPV susceptible population } \\
\hline AgMNPV + Control & 989 & $830-1.179$ & $1.47 \pm 0.11$ & $0.64^{\mathrm{ns}}$ \\
\hline$A g \mathrm{MNPV}+$ PI 274454 & 95 & $46-154$ & $0.71 \pm 0.10$ & $2.70^{\mathrm{ns}}$ \\
\hline AgMNPV + PI 227687 & 626 & $470-843$ & $1.27 \pm 0.13$ & $7.32^{\mathrm{ns}}$ \\
\hline \multicolumn{5}{|c|}{ AgMNPV resistant population } \\
\hline AgMNPV + Control & 1.345 .784 & $894.723-1.878 .755$ & $0.76 \pm 0.08$ & $4.88^{\mathrm{ns}}$ \\
\hline AgMNPV + PI 274454 & 619.637 & $339.498-965.831$ & $1.03 \pm 0.14$ & $0.62^{\mathrm{ns}}$ \\
\hline AgMNPV + PI 227687 & 2.081 .008 & $943.360-3.666 .955$ & $0.66 \pm 0.12$ & $6.47^{\mathrm{ns}}$ \\
\hline
\end{tabular}

TABLE II

Median lethal times $\left(\mathrm{LT}_{50} \mathrm{~s}\right)$, fiducial limits $(\mathbf{9 5} \%)$, slope ( $\left.\pm \mathrm{SE}\right)$ and qui-square $\left(\chi^{2}\right)$ of AgMNPV susceptible and resistant populations of Anticarsia gemmatalis fed on a soybean extract diet (PI 274454 and PI 227687) or on a plain diet (C) and different concentrations of $A g M N P V$.

\begin{tabular}{ccccc}
\hline Treatments & LT $_{50}^{1}$ & Fiducial limits $(95 \%)$ & Slope \pm SE & $\chi^{2 *}$ \\
\hline & AgMNPV susceptible population $(4,860$ OBs $/ \mathrm{ml}$ of diet $)$ & \\
\hline$A g M N P V$ & 8.66 & $8.40-8.92$ & $8.36 \pm 2.53$ & $2.53^{\mathrm{ns}}$ \\
\hline$A g$ MNPV + PI 274454 & 8.42 & $7.95-8.92$ & $4.54 \pm 0.64$ & $0.78^{\mathrm{ns}}$ \\
\hline AgMNPV + PI 227687 & 9.34 & $9.03-9.71$ & $10.36 \pm 1.19$ & $-2.08^{\mathrm{ns}}$ \\
\hline \hline & AgMNPV resistant population $(31,900,000 \mathrm{OBs} / \mathrm{ml}$ of diet) & \\
\hline AgMNPV & 8.91 & $8.59-9.28$ & $5.95 \pm 4.35$ & $4.35^{\mathrm{ns}}$ \\
\hline AgMNPV + PI 274454 & 6.72 & $6.36-7.05$ & $6.50 \pm 0.69$ & $9.93^{\mathrm{ns}}$ \\
\hline AgMNPV + PI 227687 & 8.01 & $7.65-8.38$ & $7.03 \pm 0.79$ & $6.55^{\mathrm{ns}}$ \\
\hline
\end{tabular}

${ }^{1}$ Median lethal time $\left(\mathrm{LT}_{50} \mathrm{~s}\right)$ expressed in days. $* \chi^{2}$ significant at $P<0.05$.

was highly significant ( $F=4.15, P<0.001$; Table V). When $A$. gemmatalis larvae fed on a plain diet free of $A g \mathrm{MNPV}$, they produced heavier pupae, followed by the treatment with the addition of $31,900,000$ viral $\mathrm{OB} / \mathrm{ml}$ to the diet, the largest viral concentration. For larvae fed on PI 274454 amended diet, the smallest pupal weight was observed with the largest AgMNPV concentration; pupal weight of insects from all the other treatments was not statistically different. There was no difference in A. gemmatalis pupal weights after addition of PI 227687 extracts and different concentrations of the virus to the diet (Table V). In comparison with insects fed on diets free of virus, the control diet (no virus and soybean extracts addition) produced heavier pupae than those that were fed on diets containing PI 274454 and PI
227687 extracts. After adding virus concentrations to the diet, differences in pupal weigh were no longer observed, excepting when larvae fed on diet with the highest virus concentration (31,900,000 OBs) plus PI274454 extract, in which pupa were lighter than the others.

\section{DISCUSSION}

It is known that the type of host plant and its chemical substances usually influence the progress and severity of viral infections on various lepidopteran species (Felton et al. 1987, Richter et al. 1987, Keating et al. 1988), including A. gemmatalis (Peng et al. 1997). In fact, viral activity can also be differently influenced not only by plant species and development stage (Ali et 
TABLE III

Interactions ${ }^{1}$ among (between) soybean extracts (PI 274454 and PI 227687) and six concentrations of the AgMNPV in susceptible and resistant populations to the virus.

\begin{tabular}{|c|c|c|c|c|}
\hline \multirow{3}{*}{$\begin{array}{c}\text { AgMNPV } \\
\text { concentration } \\
\text { Occlusion bodies/ } \\
\text { ml diet }\end{array}$} & \multicolumn{4}{|c|}{ D i e t $s$} \\
\hline & \multicolumn{2}{|c|}{ PI 274454} & \multicolumn{2}{|c|}{ PI 227687} \\
\hline & Effect & $\chi^{2}$ & Effect & $\chi^{2}$ \\
\hline \multicolumn{5}{|c|}{ AgMNPV susceptible population } \\
\hline 60 & Additive & $0.03^{\mathrm{ns}}$ & Additive & $2.11^{\mathrm{ns}}$ \\
\hline 180 & Additive & $2.98^{\mathrm{ns}}$ & Additive & $0.05^{\mathrm{ns}}$ \\
\hline 540 & Additive & $1.45^{\mathrm{ns}}$ & Additive & $0.89^{\mathrm{ns}}$ \\
\hline 1,600 & Additive & $0.05^{\mathrm{ns}}$ & Additive & $0.10^{\mathrm{ns}}$ \\
\hline 4,860 & Additive & $0.00^{\mathrm{ns}}$ & Additive & $0.21^{\mathrm{ns}}$ \\
\hline \multicolumn{5}{|c|}{ AgMNPV resistant population } \\
\hline 393,600 & Additive & $0.04^{\mathrm{ns}}$ & Additive & $0.39^{\mathrm{ns}}$ \\
\hline $1,181,000$ & Additive & $0.05^{\mathrm{ns}}$ & Antagonistic & $4.40^{*}$ \\
\hline $3,543,000$ & Additive & $0.19^{\mathrm{ns}}$ & Additive & $0.88^{\mathrm{ns}}$ \\
\hline $10,600,000$ & Additive & $1.48^{\mathrm{ns}}$ & Additive & $0.08^{\mathrm{ns}}$ \\
\hline $31,900,000$ & Additive & $1.03^{\mathrm{ns}}$ & Additive & $1.36^{\mathrm{ns}}$ \\
\hline
\end{tabular}

TABLE IV

Pupal weights of Anticarsia gemmatalis (S population) fed on diets containing soybean extracts (PI 274454 and PI 227687) and different AgMNPV concentrations, with the number of surviving individuals in brackets.

\begin{tabular}{|c|c|c|c|c|}
\hline \multirow{2}{*}{$\begin{array}{c}A g \mathrm{MNPV}^{1} \\
\text { concentration }\end{array}$} & \multicolumn{3}{|c|}{ Pupal weight $(\mathrm{mg}) \pm \mathrm{SE}$} & \multirow{2}{*}{$\begin{array}{c}\text { Means - } \\
\text { AgMNPV } \\
\text { concentrations }\end{array}$} \\
\hline & Control & PI 274454 & PI 227687 & \\
\hline 0 & $257.4 \pm 39.2(113)^{2}$ & $241.6 \pm 42.1(87)$ & $231.6 \pm 40.4(50)$ & $246.7 \mathrm{a}$ \\
\hline 60 & $249.4 \pm 34.7(104)$ & $231.7 \pm 45.9(66)$ & $224.4 \pm 41.2(34)$ & $239.7 \mathrm{ab}$ \\
\hline 180 & $240.2 \pm 38.5(99)$ & $227.0 \pm 46.1(54)$ & $202.7 \pm 48.8(30)$ & $230.1 \mathrm{bc}$ \\
\hline 540 & $237.6 \pm 39.0(83)$ & $221.3 \pm 42.9(37)$ & $210.8 \pm 42.9(25)$ & $228.7 \mathrm{bc}$ \\
\hline 1,600 & $223.3 \pm 34.1(55)$ & $231.2 \pm 46.3(27)$ & $210.9 \pm 44.0(20)$ & $223.1 \mathrm{c}$ \\
\hline 4,860 & $221.5 \pm 40.8(20)$ & $232.2 \pm 34.7(12)$ & $196.7 \pm 31.1(07)$ & $220.3 \mathrm{c}$ \\
\hline Means - Diets & $243.2 \mathrm{~A}$ & $232.4 \mathrm{~B}$ & $217.9 \mathrm{C}$ & \\
\hline F Value - Diets & \multicolumn{2}{|c|}{$25.96 * * *$} & & \\
\hline F Value $-A g \mathrm{M}$ & \multicolumn{2}{|c|}{$10.02 * * *$} & & \\
\hline F Value - Diets & \multicolumn{2}{|c|}{$1.08^{\mathrm{ns}}$} & & \\
\hline
\end{tabular}

Means followed by the same lowercase letter (column) and capital letter (line) are not significantly different by Tukey test at $5 \%$ probability level. $\mathrm{ns}=$ not significant, $* * * P<0.001 .{ }^{1} \mathrm{AgMNPV}$ concentration expressed in units of polyhedral occlusion bodies/ diet in biossay. ${ }^{2}$ In brackets, number of insects. 
TABLE V

Pupal weights of Anticarsia gemmatalis (R population) fed on diets containing soybean extracts (PI 274454 and PI 227687) and different AgMNPV concentrations with the number of surviving individuals in brackets.

\begin{tabular}{cccc}
\hline \multirow{2}{*}{$\begin{array}{c}\text { AgMNPV } \\
\text { concentration }\end{array}$} & \multicolumn{3}{c}{ Pupal weight (mg) \pm SEM } \\
\cline { 2 - 4 } & Control & PI 274454 & PI 227687 \\
\hline 0 & $243.9 \pm 25.8(111)^{2}$ a A & $202.7 \pm 38.5(54)$ a B & $209.8 \pm 37.4(53)$ a B \\
\hline 393,600 & $220.7 \pm 29.8(108)$ b A & $212.5 \pm 35.7(40)$ a A & $210.7 \pm 45.7(43)$ a A \\
\hline $1,180,000$ & $219.3 \pm 30.3(99)$ b A & $204.6 \pm 36.7(32)$ a A & $209.1 \pm 34.3(36)$ a A \\
\hline $3,543,000$ & $215.0 \pm 31.3(57)$ b A & $200.8 \pm 29.6(12)$ a A & $217.4 \pm 40.9(20)$ a A \\
\hline $10,600,000$ & $225.4 \pm 30.1(24)$ ab A & $173.1 \pm 21.1(6) \mathrm{b} \mathrm{B}$ & $228.5 \pm 42.7(8)$ a A \\
\hline $31,900,000$ & $19.08^{* * *}$ & & \\
\hline \hline F Value - Diets & $1.29^{\text {ns }}$ & & \\
F Value $-A g M N P V$ & $4.15^{* * *}$ & & \\
F Value - Diets $\times$ AgMNPV & & & \\
\hline
\end{tabular}

Means followed by the same lowercase (column) and capital letters (line) are not significantly different by Tukey test at $5 \%$ probability level. $\mathrm{ns}=$ not significant, $* * P<0.001 .{ }^{1} \mathrm{AgMNPV}$ concentration expressed in units of polyhedral occlusion bodies/diet in bioassay. ${ }^{2}$ In brackets, number of insect.

al. 2002) but also by different plant genotypes (SosaGomez et al. 1991). Here we compared the performance of $A$. gemmatalis fed on pure artificial diet and on diets supplemented with the crude extracts of two different soybean genotypes. Mortality of S and R populations of $A$. gemmatalis increased with the increase of viral concentration and, against our initial hypothesis, an additive effect of soybean resistant genotype extracts and AgMNPV was predominantly observed. An exception was detected for larvae fed on diet amended with PI 227687 extract and 1,181,000 occlusion bodies, in which the estimated effect was antagonistic. This effect occurred due to the mortality observed in that treatment, i.e., $67.7 \%$, which was smaller in comparison with the $73.0 \%$ mortality observed in the previous treatment $(393,600 \mathrm{OB} / \mathrm{ml}$ of diet), likely due to experimental error.

Extracts of the soybean genotypes, mainly of the PI 274454, apparently made the S and R populations more susceptible to $A g \mathrm{MNPV}$ infection, considering that the mean lethal concentration $\left(\mathrm{LC}_{50}\right)$ decreased for both populations and reinforcing the compatibility and additive effect of factors. The two genotypes whose extracts were tested here are well known sources of insect resistance and both contains phenolics, as well as the flavonoid rutin and the isoflavone genistin (Hoffmann-Campo et al. 2001, Piubelli et al. 2006) in different concentrations; foliar extracts of PI 274454 had less than half amount of the flavonoid rutin $(1.47 \mathrm{mg} / \mathrm{g})$ when compared to an estimated concentration for PI $227687(3.68 \mathrm{mg} / \mathrm{g})$. This catecholic phenolic (dihidroxyphenolic) affected biological parameters of Trichoplusia ni (Hoffmann-Campo et al. 2001), Heliothis virescens (C.B. Hoffmann-Campo, unpublished data) and A. gemmatalis (Hoffmann-Campo et al. 2006). Nevertheless, according to Felton et al. (1987), chlorogenic acid and rutin inhibited the infectivity of a single nucleopolyhedrovirus of $H$. zea (HzSNPV), but only the former was mentioned as causing negative effect on a multiple nucleopolyhedrovirus of Autographa californica (AcMNPV).

Phenolics in general can be oxidized by enzymes and other oxidants found in plant leaves, detritus, soil, water and in digestive tracts of herbivores (Appel 1993). These highly reactive products can bind to proteins, damage membranes, and are related to defensive responses of plants against herbivores (Duffey and Stout 1996, Felton et al. 1989, 1992, Appel 1993, Bi et al. 1994, Summer and Felton 1994). On the other hand, the oxidation of phenolics such as chlorogenic acid by foliar oxidative enzymes (e.g., peroxidades and polyphenol oxidases) can also decrease the infectivity of 
NPVs against H. zea (Felton and Duffey 1990) and H. virescens larvae (Hoover et al. 1998). Consequently, for a complete understanding of the interaction of plant chemical compounds and AgMNPV, experiments using soybean leaves have to be carried out.

Insect resistance to baculovirus infection can be genetic (Engelhard and Volkman 1995) or a result of the host plant chemistry (Hoover et al. 1998, 2000). These two types of resistance share a common mechanism of accelerated sloughing off infected midgut columnar cells (Hoover et al. 2000). In fact, according to these authors, sloughing off midgut epithelial cells damaged by chemicals or pathogens helps insects to quickly and effectively protect themselves against injury or death and, maybe, excreting and rapidly recovering the injured tissue. This process possibly affects susceptibility of insects to NPV by reducing the number of virions available for infection (Keating et al. 1988, 1989, Felton and Duffey 1990). However, in our test, no decrease in the virus infection was observed after adding soybean extract to an artificial diet. Indeed, baculovirus-resistant insects $(\mathrm{R})$ were more affected by the pathogen when considering weight of pupae and virus speed of kill. In the $\mathrm{R}$ population, a trend for higher $\mathrm{LC}_{50}$ was observed in the treatment AgMNPV + PI 227687, but larval mortality rates were very high; only eight, out of the 53 individuals on the control, survived when fed on such diet with the highest viral concentration. According to Levy (unpublished data), resistant A. gemmatalis population can delay viral infection likely by presenting a thicker perithrophic membrane besides of numerous citoplasmatic protusions, microvesicles and secretory vacuoles of columnar cells when compared to the susceptible population. The integrity of the peritrophic membrane in larval midgut could be affected by the ingestion of certain foliage, which allows a better virion access to midgut cell (Forschler et al. 1992). Consequently, the alteration and sloughing cells in R insects could increase the vulnerability/fragility of perithrophic membrane and thus allowing a larger amount of virus reaching the hemolymph, considering that the amount of AgMNPV ingested by this population was 6,560 times higher than that ingested by $\mathrm{S}$ population of A. gemmatalis.

The pupal weight of surviving S larvae decreased with the increase of virus concentration and varied with the addition of extracts, being higher when larvae fed on pure diet and lower in PI 227687 extract diet. On the other hand, Peng et al. (1997) observed that nutritional stress caused by plant unsuitability did not affect A. gemmatalis weight of surviving pupae. In the R population, when larvae fed on control diet, pupae were heavier than those fed on a diet with intermediate baculovirus concentration, but similar to those fed on diet plus the highest viral concentration $(31,900,000 \mathrm{OB} / \mathrm{ml}$ of diet). In this diet, the highest virus concentration did not result in significant pupal weight difference related to the untreated control, possibly due to the survivorship of the most vigorous and/or resistant insects. The same trend was observed for larvae fed on diet amended with PI 227687 diet; however, in this case, no statistical difference could be detected.

Besides mortality, virus speed of kill also varies depending on the plant type or allelochemicals (Farrar and Ridgway 2000, Raimond et al. 2002). Survival time of virally infected $H$. zea larvae was longer when feeding on diet with rutin and chlorogenic acid (Felton et al. 1987). In fact, in our studies, for A. gemmatalis ingesting the highest concentration of virus, the estimated $\mathrm{LT}_{50}$ was not different considering fiducial limits (see comments above) when the S population fed on a plain diet, and with soybean extracts. However, in the $\mathrm{R}$ population, $\mathrm{LT}_{50}$ were significantly lower when soybean extracts were added to the diet as compared to plain diet-fed insects.

Previous results (Piubelli et al. 2006) obtained with artificial diet for mass rearing of $A$. gemmatalis (without adding baculovirus) suggested that the AgMNPV-resistant population was more affected by rutin than the $\mathrm{S}$ population. To support $A$. gemmatalis growth in artificial diet it should contain $2 \%$ wet weight of casein. According to Duffey and Stout (1996), the presence of a highly nutritious protein, as casein, in the diet could increase the toxicity of phenolics, such as rutin, and thus interfere with results of experiments using these compounds. However, in further studies carried out in our laboratory (M.C. Salvador, unpublished data) insects fed on a diet with the optimal amount of casein + rutin caused less mortality, presented higher larval initial weigh and shorter feeding time than on those fed on 
diet plus half amount casein + rutin or without casein + rutin. These results suggest that the effect of rutin can be only magnified in nutritionally unbalanced diet, which was not the case in the present work. Therefore, in our studies we could note a potential of extracts containing rutin and genistin to make $A$. gemmatalis more susceptible to its nucleopolyhedrovirus or to break resistance to this virus. However, further studies using plant raw material with enzymes and mechanical traits are necessary to a better understanding of the interaction of these flavonoids with the pest and the baculovirus. This information would be important for breeding programs to select insect resistant varieties compatible with other integrated pest management strategies, such as biological control.

\section{ACKNOWLEDGMENTS}

To F.E. Paro and I. Soldório, technicians at Embrapa Soja, for helping with the bioassays, and Dr. Sheila M. Levy for the valuable discussions concerning $A$. gemmatalis midgut morphology. This research was partially supported by Programa de Apoio a Núcleos de Excelência (Pronex) Nucleus of Integrated Pest Management of the Conselho Nacional de Desenvolvimento Científico e Tecnológico (CNPq).

\section{RESUMO}

O nucleopoliedrovirus de Anticarsia gemmatalis (AgMNPV) tem sido utilizado como um inseticida biológico no Brasil. A resistência de plantas de soja a insetos tem sido pesquisada e alguns autores têm mencionado a interferência de substâncias químicas de plantas sobre a eficiência de vírus. As interações entre extratos de genótipos de soja utilizados como fontes de resistência (PI 274454 e PI 227687) com diferentes concentrações do AgMNPV em populações de A. gemmatalis suscetível (S) e resistente (R) ao vírus foram estudadas em condições de laboratório. Mortalidades elevadas foram observadas quando as larvas foram alimentadas com dietas contendo extratos dos genótipos de soja, em relação às larvas alimentadas com dieta artificial sem a presença de extratos (testemunha). A concentração letal média $\left(\mathrm{CL}_{50}\right)$ foi reduzida em aproximadamente 10 vezes, na população $\mathrm{S}$ alimentada com dieta contendo extratos da PI 274454 e diferentes concentrações do AgMNPV, comparada à dieta testemunha. Um efeito aditivo foi predominantemente observado quando as larvas se alimen- taram em dietas com extratos dos genótipos de soja (PI 274454 e PI 227687) e o AgMNPV, para ambas as populações (S e R). $\mathrm{O}$ peso de pupa foi negativamente influenciado pela dieta contendo os extratos em relação à dieta testemunha, para ambas as populações, com destaque para a população R. Os resultados indicam que, no geral, os extratos de folhas de genótipos de soja resistentes não causam efeitos negativos na eficiência do vírus.

Palavras-chave: lagarta-da-soja, baculovirus, extratos foliares, genótipos resistentes, soja.

\section{REFERENCES}

Abot AR, Moscardi F, Fuxa JR, Sosa-Gomez DR AND RICHTER AR. 1995. Susceptibility of populations of Anticarsia gemmatalis (Lepidoptera: Noctuidae) from Brazil and the United States to a nuclear polyhedrosis virus. J Entomol Sci 30: 62-69.

Abot AR, Moscardi F, FuXa JR, Sosa-Gomez DR AND RICHTER AR. 1996. Development of resistance by Anticarsia gemmatalis from Brazil and United States to a nuclear polyhedrosis virus under laboratory selection pressure. Biol Control 7: 126-130.

Ali Mi, Bi JL, Young SY, Felton GW And McNeW RW. 2002. Influence of the host plant on occluded virus production and lethal infectively of a baculovirus. J Invertebr Pathol 82: 158-165.

Appel HM. 1993. Phenolics and ecological interactions: the importance of oxidation. J Chem Ecol 19: 1521-1552.

BAnZATTO DA AND KRONKA SN. 1992. Experimentação Agrícola, Jaboticabal: Funep, 247 p.

BENZ G. 1971. Synergism of micro-organisms and chemical insecticides. In: Burges HD AND Hussey NW (Eds), Microbial control of insects and mites. London: Academic Press, p. 327-355.

Bi JL, Felton GW And Mueller AJ. 1994. Induced resistance in soybean to Helicoverpa zea: role of plant protein quality. J Chem Ecol 20: 183-198.

Duffey SS AND Stout MJ. 1996. Antinutritive and toxic components of plant defense against insects. Arch Insect Biochem Physiol 32: 3-37.

Engelhard EK AND VolKman LE. 1995. Developmental resistance within fourth instar Trichoplusia ni orally inoculated with Autographa californica M. nuclear polyhedrosis virus. Virology 209: 384-389.

FARRAR RRJ AND RIDGWAY RL. 2000. Host plant effects on the activity of selected nuclear polyhedrosis viruses against the corm earworm and beet armyworm (Lepidoptera: Noctuidae). Environ Entomol 29: 108-115. 
FEHR WR AND CAVINess CE. 1977. Stages of soybean development. Special Report 80. Ames, Iowa State Univ Sci Technol, $11 \mathrm{p}$.

FELTON GW AND DUFFEY SS. 1990. Inactivation of baculovirus by quinones formed in insect damaged plant tissues. J Chem Ecol 16: 1221-1236.

FELton GW, Duffey SS, VAil PV, Kaya HK AND MANNING J. 1987. Interaction of nuclear polyhedrosis virus with catechols: potential incompatibility for host-plant resistance against noctuid larvae. J Chem Ecol 13: 947-957.

Felton GW, Donato K, Del Vecchio RJ ANd DufFey SS. 1989. Activation of plant oxidases by insects feeding reduces the nutritive quality of foliage for noctuid herbivores. J Chem Ecol 15: 2667-2694.

FELTON GW, DONATO KK, BROADWAY RM AND DUFFEY SS. 1992. Impact of oxidized plant phenolics on the nutritional quality of dietary protein to noctuid herbivore. J Insect Physiol 38: 277-285.

FInNEY DJ. 1971. Probit analysis. London, Cambridge: Univ. Press, 333 p.

Forschler BT, Young SY AND FELton GW. 1992. Diet and the susceptibility of Helicoverpa zea (Noctuidae: Lepidoptera) to a nuclear polyhedrosis virus. Environ Entomol 21: 1220-1223.

GREene GL, LePpla NC AND Dickerson WA. 1976. Velvetbean caterpillar: a rearing procedure and artificial medium. J Econ Entomol 69: 487-488.

HofFMANN-CAMPo CB, OLIVEIRA EB AND MosCARdi F. 1985. Criação massal da lagarta da soja Anticarsia gemmatalis. Londrina: EMBRAPA-CNPSo, 23 p. (Documentos, 10).

HofFMAnN-CAMPo CB, HARBone JB AND MCCAFFERY AR. 2001. Pre-ingestive and post-ingestive effects of soybean bean extracts and rutin on Trichoplusia ni growth. Entomol Exp Appl 98: 181-194.

HofFMAnN-CAMPo CB, Oliveira LJ, Moscardi F, GAZZONI DL, CORRÊA-FERrEIRA B, LORINI IA, Borges M, PANIZzI AR, SOSA-GOMEZ DR AND CoRso I. 2003. Integrated pest management in Brazil. In: MAREdiA KM, DAKouo D AND MotA-SANChES $\mathrm{D}$ (Eds), Integrated pest management in the global arena. Trowbridge, UK: CABI Publishing, Cromwell Press, p. 285-299.

Hoffmann-CAmpo CB, Ramos Neto JA, Oliveira MCN DE AND Oliveira LJ. 2006. Detrimental effect of rutin on a main soybean defoliator pest, Anticarsia gemmatalis. Pesqui Agropecu Bras 41: 1453-1459.
Hoover K, Yee JL, Schultz CM, Rocke DM, HaMMOCK BD AND DUFFEY SS. 1998. Effects of plant identity and chemical constituents on the efficiacy of baculovirus against Heliothis virescens. J Chem Ecol 24: $221-252$.

Hoover K, Washburn JO And Volkman LE. 2000. Midgut-based resistance of Heliothis virescens to baculovirus infection mediated by phytochemicals in cotton. J Insect Physiol 46: 999-1007.

ISMAN MB AND DUfFEY SS. 1982. Toxicity of tomato phenolic compounds to fruitworm, Heliothis zea. Entomol Exp Appl 31: 370-376.

Keating ST, Yendol WG And Scultz JC. 1988. Relationship between susceptibility of gypsy moth larvae (Lepidoptera: Lymantriidae) to a baculovirus and host plant constituents. Environ Entomol 17: 952-958.

Keating ST, McCarthy WJ And Yendol WG. 1989. Gypsy moth (Lymantria dispar) larval susceptibility to a baculovirus affected by selected nutrients, hydrogen ions $(p \mathrm{H})$ and plant allelochemicals in artificial diets. J Invertebr Pathol 54: 165-174.

Morales L, Moscardi F, Sosa-Gomez DR, Paro F AND SOLdÓRIO I. 1997. Enhanced activity of Anticarsia gemmatalis Hub. (Lepidoptera: Noctuidae) nuclear polyhedrosis virus by boric acid in the laboratory. An Soc Entomol Brasil 26: 115-120.

Morales L, Moscardi F, Sosa-Gomez DR, Paro F AND SOLdÓRIO I. 2001. Fluorescent brighteners improve Anticarsia gemmatalis (Lepidoptera: Noctuidae) nucleopolyhedrovirus (AgMNPV) activity on AgMNPVsuscetible and resistant strains of the insect. Biol Control 20: 247-253.

Moscardi F. 1999. Assessment of the application of baculoviruses for control of Lepidoptera. Annu Rev Entomol 44: 257-259.

Moscardi F AND SosA-Gomez DR. 1992. Use of viruses against soybean caterpillars in Brazil. In: COPPING LG, GREEM MB AND REES RT (Eds), Pest management in soybean. Essex: SCI-Elsevier Appli Sci, p. 98-107.

Moscardi F AND SouzA ML DE. 2002. Baculovirus para o controle de pragas: panacéia ou realidade? Biotec $\mathrm{Ci}$ Des 4: 22-29.

Peng F, FuXA JR, Johnson SJ AND Richter AR. 1997. Susceptibility of Anticarsia gemmatalis (Lepidoptera: Noctuidae), reared on four host plants, to a nuclear polyhedrosis virus. Environ Entomol 26: 973-977.

Piubelli GC, Hoffmann-CAmpo CB, Moscardi F, Miyakubo SH AND Oliveira MCN DE. 2005. Are 
chemical compounds important for soybean resistance to Anticarsia gemmatalis? J Chem Ecol 31: 1509-1525.

Piubelli GC, Hoffmann-Campo CB, Moscardi F, MiyaKubo SH ANd Oliveira MCN DE. 2006. Baculovirus-resistant Anticarsia gemmatalis respond differently to dietary rutin. Entomol Exp Appl 119: 53-60.

Price PW, Bouton CE, Gross P, McPherson BA, ThOMPSON JN AND WeIS AE. 1980. Interactions among three trophic levels: influence of plant on interactions between insects herbivores and natural enemies. Annu Rev Ecol Syst 11: 41-65.

Raimond B, Vanbergen A, Pearce I, Hartley Se, CORY JS AND HAILS RS. 2002. Host plant species can influence the fitness of pathogens: a winter moth and its nucleopolyhedrovirus. Oecologia 131: 533-541.

RICHTER AR AND FUXA JR. 1984. Pathogen-pathogen and pathogen-insecticide interactions in velvetbean caterpillar (Lepidoptera: Noctuidae). J Econ Entomol 77: 15591564.

Richter AR, FuXa JR AND Abdel-Fattah M. 1987. Effects of host plant on the susceptibility of Spodoptera frugiperda (Lepidoptera: Noctuidae) to a nuclear polyhedrosis virus. Environ Entomol 16: 1004-1006.
ROSLER KH AND GOODWIN RS. 1983. A general use of Amberlite XAD-2 resin for the purification of flavonoids from aqueous fractions. J Nat Prod 47: 188.

SAS InStITUTE. 1996. SAS Propriety Software Release 6.12. SAS-STAT User's guide. Vol II. SAS Institute, Cary, N.C., 1686 p.

SosA-Gomez DR AND MoscARDi F. 2001. Resistencia de lepidópteros a los nucleopoliedrovirus: el caso de Anticarsia gemmatalis - AgMNPV. In: CABALLERO P, LÓPEZFERBER M AND Williams T (Eds), Los Baculovirus y sus aplicaciones como bioinsecticidas en el control biológico de plagas. Navarra: Phytoma-España, Universidad Pública de Navarra, p. 451-478.

SosA-Gomez DR, Alves SB And Marchini LC. 1991. Variation in the susceptibility of Bombix mori L. to nuclear polyhedrosis virus when reared on different mulberry genotytpes. J Appl Entomol 111: 318-320.

Summer CB And Felton GW. 1994. Prooxidant effects of phenolic acids on the generalist herbivore Helicoverpa zea (Lepidoptera: Noctuidae): potential mode of action for phenolic compounds in plant antiherbivore chemistry. Insect Biochem Mol Biol 24: 943-953. 